\title{
Influence of Fatty Acid Profiles during Supercritical Transesterification of Conventional and Non-Conventional Feedstocks: A Review
}

\author{
Gerald Kafuku' ${ }^{1}$, Makame Mbarawa ${ }^{2}$ \\ ${ }^{1}$ Department of Petroleum and Energy Engineering, The University of Dodoma, Dodoma, Tanzania \\ ${ }^{2}$ Ministry of Communications, Science and Technology, Dar es Salaam, Tanzania \\ Email: kafukugm@gmail.com
}

Received January 16, 2013; revised February 17, 2013; accepted March 21, 2013

Copyright (c) 2013 Gerald Kafuku, Makame Mbarawa. This is an open access article distributed under the Creative Commons Attribution License, which permits unrestricted use, distribution, and reproduction in any medium, provided the original work is properly cited.

\begin{abstract}
In this study, the influence of fatty acids of both conventional and non-conventional oils in supercritical transesterification method has been reviewed. Literature on oils such as moringa oleifera, manketti, croton megalocarpus, palm and soybean has been reviewed to establish an understanding of the supercritical transesterification that employed methanol as alcohol. This study reveals that lower yield of methyl esters is observed when higher temperatures are employed in oils that are highly dominated with polyunsaturated fatty acids, such as manketti and croton megalocarpus. And the reason is that poly-unsaturated fatty acids that are present in the oils decompose easily at higher temperatures and thus reduce the methyl esters yield.
\end{abstract}

Keywords: Fatty Acid Profile; Biodiesel; Transesterification; Supercritical Methanol

\section{Introduction}

Biodiesel is currently the most common alternative fuel that is being developed and used as a replacement for petroleum based diesel. Various feedstocks have been used to produce biodiesel ranging from the common edible oils to non-edible oils. Biodiesel, which can be prepared from various vegetable oils, has similar physical and chemical properties with petro-diesel fuel $[1,2]$. And biodiesel is further biodegradable, non-toxic, renewable, and has low emissions of $\mathrm{CO}, \mathrm{SO}_{2}$, particulates and hydrocarbons as compared to conventional diesel [3].

Generally, transesterification processes involve the displacement of alcohol from an ester by another alcohol in a reaction similar to hydrolysis, except that alcohol is used instead of water. In this reversible reaction, 1 mole of triglycerides reacts with 3 moles of alcohol to produce 1 mole of glycerol and 3 moles of fatty acid alkyl esters $[4,5]$.

The catalysts include the homogeneous catalysts such as sodium hydroxide; potassium hydroxide; sulphuric acid; and the methoxide of potassium or sodium; and the heterogeneous catalysts such as metal oxides or carbonates. The homogenous alkaline catalysts are mostly used in the biodiesel industry due to their high fatty acid methyl esters yield (more than 95\%) that can be obtained in a short reaction time $(0.5-1 \mathrm{~h})$ at mild reaction temperature $\left(50^{\circ} \mathrm{C}-60^{\circ} \mathrm{C}\right)$ [6-9]. Although homogeneous catalysts reactions are faster at moderate temperatures with better yields, there have been drawbacks associated with them. Homogeneous catalytic transesterification processes require a large amount of water to wash the produced biodiesel leading to the generation of large amounts of wastewater with high basicity or acidity which demands adequate treatment before discharging [10-12].

The use of heterogeneous catalysts in biodiesel production has been practiced due to the main advantages of easy separation and purification of the final products as well as higher tolerance towards free fatty acid (FFA) content in oils [5,11-15]. However, the heterogeneous catalysts suffer from low reactivity rate due to mass transfer limitation between liquid and solid phases of reactants and catalyst, respectively [5]. Moreover, the majority of the heterogeneous catalysts developed are quite expensive, or complicated to prepare, which limits their industrial application [16].

Many researchers have recently reported on the pro- 
duction of biodiesel by non-catalytic methods using supercritical alcohols. These methods require no catalyst, and transesterification reaction can be achieved in a very short time [17,18].

Thus, this study aims at establishing a collective understanding of the influence of fatty acid profiles of both conventional and non-conventional oils in supercritical transesterification method. The understanding is based on the efficiency of supercritical methods in converting fatty acids to methyl esters. In this study, the following oils are involved in creating this understanding; moringa oleifera, manketti (Schinziophyton rautanenii), croton megalocarpus, palm and soybean.

\section{Fatty Acid Profiles}

Before converting the fatty acids to their respective methyl esters; the structures of the crude oils are usually determined by means of a gas chromatography.

Biodiesel feedstocks vary according to location and climate, with the most abundant vegetable oil in a particular region being the most common feedstock [19]. Vegetable oils fall into edible and non-edible categories. The conventional feedstocks are oils that have normally been used for production of biodiesel and most of them are edible oils. Literature reveals that most studies have focused on the usage of pure vegetable oils for biodiesel production while very few have reported on non-conventional oils. About $84 \%$ of the world's biodiesel production comes from rapeseed oil while the remaining portion comes from sunflower oil (13\%), palm oil (1\%) and soybean oil and others (2\%) [20].

One of the ways of reducing biodiesel production costs is to use the less expensive feedstocks containing fatty acids such as non-conventional oils, animal fats, waste food oil and by-products of the refining of vegetable oils [7]. The non-conventional biodiesel feedstocks form some of the sources of biodiesel that are not utilised by human beings as food because they may either contain toxic compounds or they may be scarce, less common and expensive.

\subsection{Moringa Oleifera Oil}

Moringa oleifera is one of the oils that can be used for biodiesel production. It is derived from the seeds of the moringa oleifera tree. It is high in oleic acid (>70\%) and is commercially known as "ben oil" or "behen oil", due to its content of behenic (docosanoic) acid. Moringa oil has been reported to be widely used for the local manufacture of various herbal products for medicinal purposes [21].

Moringa oleifera is identified as indigenous to the sub-Himalayan regions of northwest India, as well as to Africa, Arabia, Southeast Asia, the Pacific and Caribbean
Islands and South America [19]. It thrives best in a tropical insular climate and is plentiful near the sandy beds of rivers and streams. It is fast growing, droughttolerant and can tolerate poor soil with a wide rainfall range (25 to $300+\mathrm{cm}$ per year) and a soil $\mathrm{pH}$ from 5.0 to 9.0. The plant starts bearing pods 6 to 8 months after planting, but regular bearing commences after the second year. When fully mature, dried moringa seeds are round or triangular in shape, and the kernel is surrounded by a lightly wooded shell with three papery wings; the seeds can produce between $33 \%$ and $41 \% \mathrm{w} / \mathrm{w}$ of vegetable oil [22]. Moringa seed has a fairly soft kernel, so the oil can be extracted by hand using a screw press. Methyl esters derived from moringa oleifera oil records high cetane numbers of above 60 which are among the highest reported for a biodiesel fuel $[19,23]$.

\subsection{Croton Megalocarpus Oil}

Croton oil is a non-edible transparent liquid of brownish colour obtained from the seeds of the croton megalocarpus plant. Croton seeds contain approximately $32 \%$ by weight of oil [24]. The plant is indigenous to the northern part of Tanzania and has been used locally as a shading tree. The plant requires relatively little water and fertilization during the cultivation stage [6]. The tree requires an annual rainfall between $800 \mathrm{~mm}$ and $1600 \mathrm{~mm}$ and average annual temperatures varying between $11^{\circ} \mathrm{C}$ and $26^{\circ} \mathrm{C}$ with a light deep, well drained soil. Seed maturity takes six months with each cone containing about 75 brown seeds [25]. The tree begins bearing nuts at 3 years and matures at about 11 years. The most reported species of croton is the Croton Tiglium, which is found in different parts of the East Indies. Its oil is mostly used in medicinal activities.

\subsection{Manketti (Schinziophyton Rautanenii) Oil}

Manketti oil is transparent edible oil, indigenous to Southern Africa, obtained from the seeds of the manketti tree. The oil is rich in phytosterols and natural proteins [26] and is mainly used in the cosmetic industry. Its habitat is the raised sandy plains of the deep Kalahari sands at an elevation of approximately $1200 \mathrm{~m}$ above sea level. Fruits are egg-shaped, velvety and contain a thin layer of edible flesh around a thick, hard pitted nutshell that encloses the edible oil-bearing kernel [27]. Only recently has manketti been explored for biodiesel production. Most reports on it focus on its use in the herbal cosmetic industry.

The research on Palm and Soybean oils regarding biodiesel production has been widely reported ranging from catalytic transesterification to non-catalytic transesterification.

Table 1 shows the fatty acid profiles of Palm [21], 
Table 1. Fatty acid profiles.

\begin{tabular}{cccccc}
\hline Fatty acid \% & Palm & $\begin{array}{c}\text { Croton } \\
\text { megalocarpus }\end{array}$ & $\begin{array}{c}\text { Moringa } \\
\text { oleifera }\end{array}$ & Manketti Soybean \\
\hline C14:0 & - & 0.1 & - & - & - \\
C16:0 & 42.6 & 6.5 & 7.6 & 9.8 & 11 \\
C16:1 & 0.3 & 0.1 & 1.4 & - & - \\
C17:0 & - & 0.1 & - & - & - \\
C18:0 & 4.4 & 3.8 & 5.5 & 7.2 & 4 \\
C18:1 & 40.5 & - & - & - & 23.4 \\
C18:2 & 10.1 & - & - & - & 53.2 \\
C18:3 & 0.2 & - & - & - & 7.8 \\
C18:1 cis & - & 11.6 & 66.6 & 16.4 & - \\
C18:2 cis & - & 72.7 & 8.1 & 43.4 & - \\
C18:3 n6 & - & 0.4 & - & - & - \\
C18:3 n3 & - & 3.5 & 0.2 & - & - \\
C20:0 & 0.2 & - & 5.8 & 0.2 & - \\
C20:1 & - & 0.9 & 1.7 & 0.3 & - \\
C20:2 & - & 0.2 & - & 0.2 & - \\
C20:5 & - & - & - & 22.6 & - \\
\hline
\end{tabular}

Soybean [1] and croton, moringa and manketti oils [22]. From the table, it can be seen that croton, soybean and manketti oils contain higher amounts of polyunsaturated fatty acids than palm and moringa oils.

\section{Transesterification}

Transesterification is also known as alcoholysis. It involves the displacement of alcohol from an ester by another alcohol in a manner similar to hydrolysis, except that alcohol is used instead of water. It is the current method of choice employed to produce biodiesel by either the batch or continuous process, with the purpose of lowering the viscosity of oil or fat [28]. Transesterification is basically the reaction of a fat or oil triglyceride with an alcohol to form esters and glycerol [23]; a catalyst is usually used to improve the reaction rate and yield [29], and because the reaction is reversible, excess alcohol is used to shift the equilibrium to the product side [4, $5,28]$. When triglycerides react with alcohol, the three fatty acid chains are released from the glycerol skeleton and combine with the alcohol to form fatty acid alkyl esters with glycerol produced as a by-product. The most commonly prepared esters are methyl esters, largely because methanol is the least expensive alcohol [30]. Among the alcohols that can be used in the transesterification reaction are methanol, ethanol, propanol, butanol and amyl alcohol. Methanol and ethanol are used most frequently. The use of ethanol in the transesterification process has been preferred because it is derived from agricultural products and is renewable as well as biologically less objectionable in the environment [31]. However, ethanol is more expensive and less reactive than methanol; the ethyl esters are less stable and leave a greater carbon residue. Therefore, methanol is mostly preferred for large-scale production of biodiesel due to its low cost and the advantages as regards its physical and chemical properties, that is, polar and shortest chain alcohol.

\subsection{One step alkaline Catalytic Transesterification Process}

This is the process for biodiesel production which is preferred for feedstocks with a normal or lower content of FFAs. Usually the feedstocks of this kind are edible oils. Generally, when the FFA level is less than $2 \%$, and certainly if it is less than $0.5 \%$, the FFAs can be ignored [32]. An alkaline-catalysed transesterification process is the most preferred biodiesel production method because alkaline metal alkoxides and hydroxides are more effective transesterification catalysts than the acid catalysts, although for economic reasons hydroxides are more often used. Transesterification occurs at a faster rate in the presence of an alkaline catalyst than in the presence of the same amount of acid catalyst. Sodium alkoxides (sodium methoxide, for example), potassium hydroxide $(\mathrm{KOH})$ and sodium hydroxide $(\mathrm{NaOH})$ are the most efficient catalysts used for this purpose [1]. In using $\mathrm{KOH}$ or $\mathrm{NaOH}$ as a catalyst for alkaline transesterification, the catalyst $(\mathrm{KOH}$ or $\mathrm{NaOH})$ is dissolved into methanol by vigorous stirring in a small reactor. The oil is transferred into a biodiesel reactor after which the catalyst/alcohol mixture is pumped into the oil. The final mixture is stirred vigorously for a chosen time and temperature under ambient pressure. A successful transesterification reaction produces two liquid phases: ester and crude glycerin. Although alkali-catalysed transesterification is much faster than acid catalysts, it is not suitable for esterification of free fatty acids, because alkaline catalysts are very sensitive to free fatty acids. During the reaction, free fatty acids may react with an alkali catalyst to form soap and water, which diminishes the ester yield [10]; acid catalysts such as sulphuric or hydrochloric acid are preferred for the esterification of free fatty acids. In addition, acid-catalyzed esterification reaction of free fatty acids is relatively faster than acid-catalyzed transesterification reaction of triglycerides [33].

\subsection{Two Step Acid-Base Catalytic Transesterification Process}

The technology for converting edible oil to biodiesel has 
been well established; however, the main issue in converting non-edible oil into biodiesel is always associated with the high free fatty acid content. A two-step transesterification process has been shown to function well in the production of biodiesel from feedstocks with high FFA content. In the initial step, the free fatty acid content of oil is reduced by an acid-catalyzed esterification process; thereafter, during the second step, an alkaline-catalyzed process is used to convert the pre-treated oil to methyl esters and glycerol. As noted, many researchers have found two step acid-catalyzed esterification very effective for the transesterification of feedstocks possessing high FFA content, with the yield of biodiesel in the overall process exceeding $90 \%[7,20,34,35]$.

\subsection{Heterogeneous Catalyzed Transesterification Process}

The use of heterogeneous catalysts is preferred due to easy separation and purification of the final products [11-15]. Basically, there are three types of heterogeneous catalyst being used in the transesterification process: acid, base and enzyme. The particular method, in which these heterogeneous catalysts are used, is generally named after the type of the catalyst itself [13]. However, heterogeneous catalysts suffer from low reactivity rates due to mass transfer limitations between the liquid and solid phases of the reactants and catalyst, respectively [5]. Again, the majority of the heterogeneous catalysts developed are quite expensive or complicated to prepare, which limits their industrial application [16].

\subsection{Supercritical Transesterification}

Most literature has reported that more biodiesel was produced when the transesterification process employed a catalyst to accelerate the methylation step because the solubility of oil in methanol is poor [36]. However, as it was stated earlier that the catalytic transesterification processes have evidenced drawbacks such as difficulties in the separation and purification of the final products, for homogeneous catalysts, and low reactivity rates, for heterogeneous catalysts. This led researchers to investigate new methods of transesterification while eliminating the problems associated with the catalytic transesterification methods.

The supercritical methanol method is one of the non-catalytic methods recently employed in attempting to solve the problems associated with catalytic transesterification [37-39]. The method was introduced in 2001 for the purpose of avoiding the use of a catalyst and completing transesterification in a relatively short time $[17,18,40]$. The method is a simple process with a high yield because of the simultaneous transesterification of triglycerides and methyl esterification of fatty acids [41].
In this process, ions are produced from the alcohol and the mixture of oil and alcohol is combined as a single phase, which causes the acceleration of the reaction [42]. High methyl esters yields of above $90 \%$ have been reported with respect to the use of supercritical alcohol in biodiesel production [43-46]. Compared with catalytic processes under barometric pressure, the supercritical methanol process is much simpler for purifying the products, as well as lowering the reaction time, and is more environmentally friendly [47].

However, the non-catalytic methods exhibit drawbacks associated with the high cost of equipment because of operating under high temperatures and pressures, which are not viable in large scale practice in industry [18, $46,48]$. The problem of supercritical methods requiring high energy to reach completion has been of great concern. Tan, et al. [49] reported that the supercritical method requires the temperature and pressure above $239^{\circ} \mathrm{C}$ and $8.1 \mathrm{MPa}$ respectively in order to achieve supercritical methanol state that makes these technologies an energy-intensive process. Co-solvents, such as carbon dioxide [50], heptane [39] and calcium oxide [47] added into the reaction mixture have been reported to decrease the operating temperature, pressure and the amount of alcohol.

\section{Observed Results during Supercritical Transesterification}

During supercritical transesterification, Palm and moringa oils did show good methyl esters yields when reaction parameters such as temperature and time were increased; however, a slight decrease in yield has been observed when temperature is further increased [48,51]. Palm and moringa oils are highly dominated with monounsaturated fatty acids. The yields for longer reaction time are higher than that for shorter reaction time. This is because short reaction time is not sufficient to push the reaction to completion particularly at lower temperature where transesterification rate is slower, while, longer reaction time allows the reaction to attain higher yield even though at low reaction temperature [52]. However, increasing reaction temperature favored higher biodiesel yield for both short and long reaction time. This is because transesterification reaction rate has a strong dependency on temperature. This explains that higher yield of biodiesel can be achieved even though shorter reaction period was used, provided reaction temperature is sufficiently high [53]. Further increase in temperature resulted in lower yield for longer reaction time than for shorter reaction time. This is because transesterification is a reversible reaction that higher temperature with longer reaction time tends to reverse back the reaction [9, 54]. Low yields at severe high temperature might be attributed by the decomposition of poly-unsaturated methyl 
esters and unreacted triglycerides $[4,51,55]$.

Higher temperatures with short period time did favor the high yields of methyl esters from soybean oil [37], however, the yield of methyl ester decreased at higher temperatures with longer reaction time because soybean oil has also high dominance of polyunsaturated fatty acids that influence methyl esters yields at high temperatures.

Croton and manketti oils show similar behaviour during supercritical transesterification. This might be attributed to the strong dominance of polyunsaturated fatty acids in these oils. Manketti largely comprises linoleic and eicosapentaenoic acids while croton mostly consists of linoleic acid. It was generally observed that higher temperatures, and thus higher pressure, did not favour the transesterification reaction; hence, the yields for lower temperatures were higher than the yields for higher temperatures [53]. This is because the poly-unsaturated fatty acids that are present in the oils decompose easily at higher temperatures and thus reduce the methyl esters yield $[55,56]$.

\section{Summary}

The influence of fatty acid composition of oils for biodiesel production is well observed when reaction parameters such as time and temperature are varied. Higher temperatures with short period time favor high yields of methyl esters while higher temperatures with longer reaction time do not. Higher temperatures do not favor the supercritical methanol method for transesterification of oils with a high dominance of polyunsaturated fatty acids such as croton and manketti oils. Little has been reported on the supercritical transesterification of non-conventional oils, such as moringa, manketti and croton oils compared to other oils such as Palm and soybean.

\section{REFERENCES}

[1] U. Rashid and F. Anwar, "Production of Biodiesel through Optimized Alkaline-Catalyzed Transesterification of Rapeseed Oil,” Fuel, Vol. 87, No. 3, 2008, pp. 265-273. doi:10.1016/j.fuel.2007.05.003

[2] Z. Helwani, et al., "Solid Heterogeneous Catalysts for Transesterification of Triglycerides with Methanol: A Review," Applied Catalysis A: General, Vol. 363, No. 1-2, 2009, pp. 1-10. doi:10.1016/j.apcata.2009.05.021

[3] K. Noiroj, et al., "A Comparative Study of KOH/Al2O3 and $\mathrm{KOH} / \mathrm{NaY}$ Catalysts for Biodiesel Production via Transesterification from Palm Oil," Renewable Energy, Vol. 34, No. 4, 2009, pp. 1145-1150. doi:10.1016/j.renene.2008.06.015

[4] E.-S. Song, et al., "Transesterification of RBD Palm Oil Using Supercritical Methanol,” The Journal of Supercritical Fluids, Vol. 44, No. 3, 2008, pp. 356-363. doi:10.1016/j.supflu.2007.09.010
[5] K. T. Tan, et al., "An Optimized Study of Methanol and Ethanol in Supercritical Alcohol Technology for Biodiesel Production," The Journal of Supercritical Fluids, Vol. 53, No. 1-3, 2010, p. 82-87.

doi:10.1016/j.supflu.2009.12.017

[6] G. Kafuku, et al., "Croton Megalocarpus Oil: A Feasible Non-Edible Oil Source for Biodiesel Production,” Bioresource Technology, Vol. 101, No. 18, 2010, pp. 7000 7004. doi:10.1016/j.biortech.2010.03.144

[7] H. J. Berchmans and S. Hirata, "Biodiesel Production from Crude Jatropha curcas L. Seed Oil with a High Content of Free Fatty Acids,” Bioresource Technology, Vol. 99, No. 6, 2008, pp. 1716-1721. doi:10.1016/j.biortech.2007.03.051

[8] J. M. Dias, M. C. M. Alvim-Ferraz and M. F. Almeida, "Comparison of the Performance of Different Homogeneous Alkali Catalysts during Transesterification of Waste and Virgin Oils and Evaluation of Biodiesel Quality,” Fuel, Vol. 87, No. 17-18, 2008, pp. 3572-3578. doi:10.1016/j.fuel.2008.06.014

[9] T. Eevera, K. Rajendran and S. Saradha, "Biodiesel Production Process Optimization and Characterization to Assess the Suitability of the Product for Varied Environmental Conditions,” Renewable Energy, Vol. 34, No. 3, 2009, pp. 762-765. doi:10.1016/j.renene.2008.04.006

[10] G. Guan, K. Kusakabe and S. Yamasaki, "Tri-Potassium Phosphate as a Solid Catalyst for Biodiesel Production from Waste Cooking Oil,” Fuel Processing Technology, Vol. 90, No. 4, 2009, pp. 520-524. doi:10.1016/j.fuproc.2009.01.008

[11] M. Kouzu, et al., "Calcium Oxide as a Solid Base Catalyst for Transesterification of Soybean Oil and Its Application to Biodiesel Production,” Fuel, Vol. 87, No. 12, 2008, pp. 2798-2806. doi:10.1016/j.fuel.2007.10.019

[12] M. Zabeti, W. M. A. W. Daud and M. K. Aroua, "Optimization of the Activity of $\mathrm{CaO} / \mathrm{Al} 2 \mathrm{O} 3$ Catalyst for Biodiesel Production Using Response Surface Methodology,” Applied Catalysis A: General, Vol. 366, No. 1, 2009, pp. 154-159. doi:10.1016/j.apcata.2009.06.047

[13] J. Kansedo, K. T. Lee and S. Bhatia, "Biodiesel Production from Palm Oil via Heterogeneous Transesterification,” Biomass and Bioenergy, Vol. 33, No. 2, 2009, pp. 271-276. doi:10.1016/j.biombioe.2008.05.011

[14] K. G. Georgogianni, et al., "Transesterification of Soybean Frying Oil to Biodiesel Using Heterogeneous Catalysts,” Fuel Processing Technology, Vol. 90, No. 5, 2009, pp. 671-676. doi:10.1016/j.fuproc.2008.12.004

[15] G. Arzamendi, et al., "Synthesis of Biodiesel with Heterogeneous $\mathrm{NaOH} /$ Alumina Catalysts: Comparison with Homogeneous NaOH,” Chemical Engineering Journal, Vol. 134, No. 1-3, 2007, pp. 123-130. doi:10.1016/j.cej.2007.03.049

[16] M. C. G. Albuquerque, et al., " $\mathrm{CaO}$ Supported on Mesoporous Silicas as Basic Catalysts for Transesterification Reactions,” Applied Catalysis A: General, Vol. 334, No. 1-2, 2008, pp. 35-43. doi:10.1016/j.apcata.2007.09.028

[17] A. Demirbas, "Biodiesel from Vegetable Oils via Trans- 
esterification in Supercritical Methanol," Energy Conversion and Management, Vol. 43, No. 17, 2002, pp. 23492356. doi:10.1016/S0196-8904(01)00170-4

[18] J.-Z. Yin, M. Xiao and J.-B. Song, "Biodiesel from Soybean Oil in Supercritical Methanol with Co-Solvent," Energy Conversion and Management, Vol. 49, No. 5, 2008, pp. 908-912. doi:10.1016/j.enconman.2007.10.018

[19] U. Rashid, et al., "Moringa Oleifera Oil: A Possible Source of Biodiesel,” Bioresource Technology, Vol. 99, No. 17, 2008, pp. 8175-8179. doi:10.1016/j.biortech.2008.03.066

[20] M. M. Gui, K. T. Lee and S. Bhatia, "Feasibility of Edible Oil vs. Non-Edible Oil vs. Waste Edible Oil as Biodiesel Feedstock," Energy, Vol. 33, No. 11, 2008, pp. 1646-1653. doi:10.1016/j.energy.2008.06.002

[21] F. Anwar, et al., "Moringa Oleifera: A Food Plant with Multiple Medicinal Uses," Phytotherapy Research, Vol. 21, No. 1, 2007, pp. 17-25. doi:10.1002/ptr.2023

[22] A. Sengupta and M. P. "Gupta, Studies on the Seed Fat Composition of Moringacea Family,” Fette, Seifen, Anstrichm, Vol. 72, No. 1, 1970, pp. 6-10. doi:10.1002/lipi.19700720103

[23] G. Kafuku, et al., "Heterogeneous Catalyzed Biodiesel Production from Moringa Oleifera Oil,” Fuel Processing Technology, Vol. 91, No. 11, 2010, pp. 1525-1529. doi:10.1016/j.fuproc.2010.05.032

[24] Kafuku, G. and M. Mbarawa, "Biodiesel Production from Croton Megalocarpus Oil and Its Process Optimization,” Fuel, Vol. 89, No. 9, 2010, pp. 2556-2560. doi:10.1016/j.fuel.2010.03.039

[25] B. Aliyu, B. Agnew and S. Douglas, "Croton Megalocarpus (Musine) Seeds as a Potential Source of Bio-Diesel," Biomass and Bioenergy, Vol. 34, No. 10, 2010, pp. 1495-1499. doi:10.1016/j.biombioe.2010.04.026

[26] M. Athar and S. M. Nasir, "Taxonomic Perspective of Plant Species Yielding Vegetable Oils Used in Cosmetics and Skin Care Products," African Journal of Biotechnology, Vol. 4, No. 1, 2005, pp. 36-44.

[27] J. H. Pratt, et al., "Malawi Agroforestry Extension Project Marketing \& Enterprise Program, Main Report," Malawi Agroforestry, 2002, p. 139.

[28] A. Demirbas, "Biodiesel: A Realistic Fuel Alternative for Diesel Engines,” Springer Verlag, Berlin, 2008.

[29] C.-H. Chen, et al., "Biodiesel Production from Supercritical Carbon Dioxide Extracted Jatropha oil Using Subcritical Hydrolysis and Supercritical Methylation," The Journal of Supercritical Fluids, Vol. 52, No. 2, 2010, pp. 228-234. doi:10.1016/j.supflu.2009.12.010

[30] G. Knothe, et al., “The Biodiesel Handbook,” AOCS Press, Champaign, 2005.

[31] A. Demirbas, "Biodiesel Production from Vegetable Oils via Catalytic and Non-Catalytic Supercritical Methanol Transesterification Methods," Progress in Energy and Combustion Science, Vol. 31, No. 5-6, 2005, pp. 466-487. doi:10.1016/j.pecs.2005.09.001

[32] J. Van Gerpen, et al., "Biodiesel Production Technology. Report for the National Renewable Energy Laboratory,”
Department of Energy, Washington DC, 2004, pp. 30-42.

[33] A. Keskin, M. Gürü and D. Altiparmak, "Biodiesel Production from Tall Oil with Synthesized Mn and Ni Based Additives: Effects of the Additives on Fuel Consumption and Emissions," Fuel, Vol. 86, No. 7-8, 2007, pp. 11391143. doi:10.1016/j.fuel.2006.10.021

[34] A. Kumar Tiwari, A. Kumar and H. Raheman, "Biodiesel Production from Jatropha Oil (Jatropha curcas) with High Free Fatty Acids: An Optimized Process,” Biomass and Bioenergy, Vol. 31, No. 8, 2007, pp. 569-575. doi:10.1016/j.biombioe.2007.03.003

[35] X. Meng, G. Chen and Y. Wang, "Biodiesel Production from Waste Cooking Oil via Alkali Catalyst and Its Engine Test,” Fuel Processing Technology, Vol. 89, No. 9, 2008, pp. 851-857. doi:10.1016/j.fuproc.2008.02.006

[36] C.-H. Chen, W.-H. Chen, C.-M. J. Chang, S.-M. Lai and C.-H. Tu, "Biodiesel Production from Supercritical Carbon Dioxide Extracted Jatropha Oil Using Subcritical Hydrolysis and Supercritical Methylation,” The Journal of Supercritical Fluids, Vol. 52, No. 2, 2010, pp. 228-234. doi:10.1016/j.supflu.2009.12.010

[37] C. Zhou, et al., "Continuous Production of Biodiesel from Soybean Oil Using Supercritical Methanol in a Vertical Tubular Reactor: I. Phase Holdup and Distribution of Intermediate Product along the Axial Direction," Chinese Journal of Chemical Engineering, Vol. 18, No. 4, 2010, pp. 626-629. doi:10.1016/S1004-9541(10)60266-2

[38] S. Hawash, et al., "Biodiesel Fuel from Jatropha Oil via Non-Catalytic Supercritical Methanol Transesterification,” Fuel, Vol. 88, No. 3, 2009, pp. 579-582. doi:10.1016/j.fuel.2008.09.007

[39] K. T. Tan, K. T. Lee and A. R. Mohamed, "Effects of Free Fatty Acids, Water Content and Co-Solvent on Biodiesel Production by Supercritical Methanol Reaction," The Journal of Supercritical Fluids, Vol. 53, No. 1-3, 2010, pp. 88-91. doi:10.1016/j.supflu.2010.01.012

[40] J.-S. Lee and S. Saka, "Biodiesel Production by Heterogeneous Catalysts and Supercritical Technologies," Bioresource Technology, Vol. 101, No. 19, 2010, pp. 71917200. doi:10.1016/j.biortech.2010.04.071

[41] A. Demirbas, "Biodiesel Production via Non-Catalytic SCF Method and Biodiesel Fuel Characteristics,” Energy Conversion and Management, Vol. 47, No. 15-16, 2006, pp. 2271-2282. doi:10.1016/j.enconman.2005.11.019

[42] R. Alenezi, et al., "Esterification Kinetics of Free Fatty Acids with Supercritical Methanol for Biodiesel Production,” Energy Conversion and Management, Vol. 51, No. 5, 2010, pp. 1055-1059. doi:10.1016/j.enconman.2009.12.009

[43] D. Kusdiana and S. Saka, "Methyl Esterification of Free Fatty Acids of Rapeseed Oil as Treated in Supercritical Methanol," Journal of Chemical Engineering of Japan, Vol. 34, No. 3, 2001, pp. 383-387. doi:10.1252/jcej.34.383

[44] A. Demirbas, "Comparison of Transesterification Methods for Production of Biodiesel from Vegetable Oils and Fats,” Energy Conversion and Management, Vol. 49, No. 1, 2008, pp. $125-130$. 
doi:10.1016/j.enconman.2007.05.002

[45] A. Demirbas, "Studies on Cottonseed Oil Biodiesel Prepared in Non-Catalytic SCF Conditions," Bioresource Technology, Vol. 99, No. 5, 2008, pp. 1125-1130. doi:10.1016/j.biortech.2007.02.024

[46] H. He, T. Wang and S. Zhu, "Continuous Production of Biodiesel Fuel from Vegetable Oil Using Supercritical Methanol Process,” Fuel, Vol. 86, No. 3, 2007, pp. 442447. doi:10.1016/j.fuel.2006.07.035

[47] A. Demirbas, "Biodiesel from Sunflower Oil in Supercritical Methanol with Calcium Oxide,” Energy Conversion and Management, Vol. 48, No. 3, 2007, pp. 937-941. doi:10.1016/j.enconman.2006.08.004

[48] Joelianingsih, et al., "Biodiesel Fuels from Palm Oil via the Non-Catalytic Transesterification in a Bubble Column Reactor at Atmospheric Pressure: A Kinetic Study,” Renewable Energy, Vol. 33, No. 7, 2008, pp. 1629-1636. doi:10.1016/j.renene.2007.08.011

[49] K. T. Tan and K. T. Lee, "A Review on Supercritical Fluids (SCF) Technology in Sustainable Biodiesel Production: Potential and Challenges," Renewable and Sustainable Energy Reviews, Vol. 15, No. 5, 2011, pp. 24522456. doi:10.1016/j.rser.2011.02.012

[50] M. N. Varma, P. A. Deshpande and G. Madras, "Synthesis of Biodiesel in Supercritical Alcohols and Supercritical Carbon Dioxide,” Fuel, Vol. 89, No. 7, 2010, pp.
1641-1646. doi:10.1016/j.fuel.2009.08.012

[51] K. T. Tan, K. T. Lee and A. R. Mohamed, "Production of FAME by Palm Oil Transesterification via Supercritical Methanol Technology,” Biomass and Bioenergy, Vol. 33, No. 8, 2009, pp. 1096-1099. doi:10.1016/j.biombioe.2009.04.003

[52] G. Kafuku, et al., "Noncatalytic Biodiesel Fuel Production from Croton megalocarpus Oil," Chemical Engineering \& Technology, Vol. 34, No. 11, 2011, pp. 18271834. doi:10.1002/ceat.201100204

[53] G. Kafuku, "Production of Biodiesel from Non-Edible Oils,” Tshwane University of Technology, Pretoria, 2011.

[54] G. Kafuku, et al., "Heterogeneous Catalyzed Biodiesel Production from Moringa oleifera Oil,” Fuel Processing Technology, Vol. 91, No. 11, 2010, pp. 1525-1529. doi:10.1016/j.fuproc.2010.05.032

[55] H. Imahara, et al., "Thermal Stability of Biodiesel in Supercritical Methanol,” Fuel, Vol. 87, No. 1, 2008, pp. 1-6. doi:10.1016/j.fuel.2007.04.003

[56] J. Xin, H. Imahara and S. Saka, "Oxidation Stability of Biodiesel Fuel as Prepared by Supercritical Methanol," Fuel, Vol. 87, No. 10-11, 2008, pp. 1807-1813. doi:10.1016/j.fuel.2007.12.014 